\title{
Soil-Surface Straw Influences Micrometeorological Conditions Affecting Canola Mortality During Nighttime Frosts
}

\author{
Samuel Kovaleski ${ }^{1}$, Arno B. Heldwein ${ }^{1}$, Genei A. Dalmago ${ }^{2}$, Jorge A. de Gouvêa ${ }^{2}$, Gilberto R. da Cunha ${ }^{2}$ \\ $\&$ Elizandro Fochesatto ${ }^{3}$ \\ ${ }^{1}$ Universidade Federal de Santa Maria, Santa Maria, Rio Grande do Sul, Brazil \\ ${ }^{2}$ Embrapa Trigo, Passo Fundo, Rio Grande do Sul, Brazil \\ ${ }^{3}$ Universidade Alto Vale do Rio do Peixe, Caçador, Santa Catarina, Brazil \\ Correspondence: Samuel Kovaleski, Universidade Federal de Santa Maria, Santa Maria, Rio Grande do Sul, Brazil. \\ Tel: 54-991-121-933. E-mail: samtotes@hotmail.com
}

Received: July 17, 2020

doi:10.5539/jas.v12n11p246
Accepted: September 26, $2020 \quad$ Online Published: October 15, 2020

URL: https://doi.org/10.5539/jas.v12n11p246

\begin{abstract}
Our objective was to measure alterations in the micrometeorological conditions surrounding canola seedlings during frost periods, and to quantify seedling mortality as a function of straw distribution on the ground surface. The data was acquired from 15 frosts in 2014. We used four treatments, comprising ground surface without straw (SWS), ground surface entirely straw-covered (SEC), sowing line without straw (SLW), and soil with preexisting surface straw (SES), over three experiments. Net radiation (NR), soil heat flux (G), air (Ta), leaf (Lf), rosette (Tr), and surface temperature (Ts), and plant mortality were evaluated. NR was higher in the SEC treatment and lower in the SLW treatment, whereas G was higher on straw-covered ground; Ts and Ta were lower in the SEC than in the other treatments during the most intense frosts. On 06/19, Tr in the SEC and SLW treatments was $-0.66{ }^{\circ} \mathrm{C}$ and $0.42{ }^{\circ} \mathrm{C}$, respectively; on $08 / 14$, Lf was $-3.62{ }^{\circ} \mathrm{C}$ and $-2.88^{\circ} \mathrm{C}$ in the SEC and SLW treatments, respectively. Plant mortality due to the frost on $06 / 19$ was $30 \%$ in the SEC treatment, but $0 \%$ in the SLW treatment; the frost of 08/14 caused $33.8 \%$ mortality in the SEC treatment and $1.25 \%$ in the SLW treatment. This therefore showed that removing straw from the sowing line improved the microclimate around the plants, thus reducing canola mortality at the beginning of the growth cycle, which is when frost events most frequently occur.
\end{abstract}

Keywords: air temperature, Brassica napus L., freezing, leaf temperature, microclimate

\section{Introduction}

Canola (Brassica napus L.) plants are susceptible to frost damage at the beginning of their development cycle (Sovero, 1993; Dalmago et al., 2010; Fiebelkorn \& Rahman, 2016; Jan et al., 2017). Air temperatures of $-2{ }^{\circ} \mathrm{C}$ to $-6^{\circ} \mathrm{C}$ may cause significant harm to plants with one to five leaves, and may even lead to plant death (Sovero, 1993; Wilen, et al., 1994; Thomas, 2003; McClinchey \& Kott, 2008; Dalmago et al., 2010; Fiebelkorn \& Rahman, 2016; Jan et al., 2017). This is a problem in southern Brazil, where frosts frequently occur suddenly, allowing no previous period of frost-acclimation for the canola (Dalmago et al., 2010).

The residual straw present in no-tillage systems interferes with the radiation balance (Chen \& McKyes, 1993; Raine \& So, 1993; Horton et al., 1996; Azooz et al., 1997; Davin et al., 2014; Cierniewski et al., 2015; O'Brien \& Daigh, 2019). According to O'Brien and Daigh (2019), the soil surface type affects resistance to both vertical air and latent heat fluxes. Resistance to the former is lower on straw-covered compared with bare ground, because the rough texture of the straw cover increases its contact surface, resulting in a greater energy exchange with the adjacent air (Van Doren \& Allmaras, 1978; Lal \& Stewart, 2012). Moreover, the thermal conductivity of straw is lower than that of clay soil (Ahn et al., 2009). This may mean that, during frosts, the coldest air temperatures are found immediately above the ground surface (Kaspar \& Erbadch, 1998; O'Brien \& Daigh, 2019), and that canola seedlings, which are closer to the straw, may therefore exhibit more severe damage. However, the influence of soil surface straw on the environmental variables involved in energy balance and air temperatures during frosts is not well understood (O'Brien \& Daigh, 2019), and studies quantifying how soil surface straw influences frost damage in canola seedling are also scarce. Moreover, most of the available information about frost damage in canola and 
other field crops has been obtained using artificial frost, which is limited in its ability to reflect natural frost conditions (Frederiks et al., 2012; Martino \& Abbate, 2019).

Given the importance of no-tillage farming systems in Brazil, together with the prevalence of frosts that damage canola seedlings, a better understanding of the influence of the soil surface type on micrometeorological variables and the response of canola plants to cold is required. Quantifying micrometeorological variables in the soil-plant-atmosphere interface during periods of frost can improve the agroclimatic zoning of canola, and aid in the establishment of growth and development models.

Thus, the objective of this study was to identify and quantify alterations in the micrometeorological conditions surrounding canola seedlings during periods of frost, and to quantify seedling mortality as a function of the distribution of straw on the ground surface.

\section{Materials and Methods}

\subsection{Study Location}

In 2014, the effects of frost events $(n=15)$ on canola were evaluated in three experiments, under field conditions, in the research area of the Embrapa Trigo, in Coxilha, RS, Brazil $\left(28^{\circ} 10^{\prime} \mathrm{S}, 52^{\circ} 19^{\prime} \mathrm{W}\right.$; altitude, $\left.686 \mathrm{~m}\right)$. According to Köppen's classification, the climate of the region is Cfa (subtropical wet with warm summer) (Alvares et al., 2013). The soil type in the research area is Rhodic Hapludox. The average declivity of about of 3-5\% is similar to most grain fields in the southern region of Brazil.

\subsection{Experimental Design}

The three experiments were sown on April 23 (experiment 1), May 29 (experiment 2), and July 16 (experiment 3), 2014, these dates being within the period when frosts were most likely to occur in the region (May to August) (Alvares et al., 2013). The experimental design was a complete randomized block with four replicates. Each experimental unit (area, $30 \mathrm{~m}^{2}$; length, $6 \mathrm{~m}$ ), contained 16 rows of canola plants oriented in an E-W direction along the width of the unit. The treatments consisted of four straw distribution patterns: ground surface without straw (SWS), ground surface entirely covered with straw (SEC), sowing line without straw (SLW), and soil with preexisting surface straw (SES). Fertilization was based on the canola requirements and soil analysis. Weeds and insects were controlled in accordance with standard guidelines for canola (Thomas, 2003).

There were preexisting straw residues of $4300 \mathrm{~kg} \mathrm{ha}^{-1}$ at the soil surface; this was therefore the quantity present in the SES treatment, and disruption of the soil covering was generated solely by the passage of the seeder. In the SWS treatment, preexisting residues were completely removed from the soil surface. In the SEC treatment, 3000 $\mathrm{kg} \mathrm{ha}^{-1}$ of soybean straw was distributed on top of the preexisting crop residues, therefore totaling $7300 \mathrm{~kg} \mathrm{ha}^{-1}$. Finally, in the SLW treatment, straw was removed to a distance of approximately $5 \mathrm{~cm}$ from each side of the sowing lines and repositioned between the lines. In addition, $1500 \mathrm{~kg} \mathrm{ha}^{-1}$ of soybean straw was added in order to replicate the quantity of straw and extent of surface coverage in the SEC treatment.

\subsection{Measurements and Analysis}

Evaluations of both the micrometeorological and plant variables were performed up to the D2 stage (bud covered with visible secondary inflorescences) of the canola, based on the phenological scale proposed by the Centre Technique Interprofessionnel des Oléagineux et du Chanvre (CETIOM). Micrometeorological monitoring was only conducted in the first and second experiments (one experimental unit per treatment), owing to the limited availability of equipment and sensors.

Net radiation (NR) in the canola canopy was measured using net radiometers (NR-LITE-2, Kipp \& Zonen, Delft, The Netherlands). A net radiometer was installed at a height of $1.0 \mathrm{~m}$ in the center of an experimental unit per treatment. Soil heat flux $(\mathrm{G})$ was measured using heat flux sensors (HFP01-15, Campbell Scientific, Logan, USA) installed at a depth of $0.01 \mathrm{~m}$; two heat flow plates were installed per treatment (one in the center between two sowing rows and one in the sowing line between two plants). Wind speed (U) and direction (UD) were measured using ultrasonic anemometers (WINDSONIC 1-L34, Campbell Scientific, Logan, USA), which were installed at a height of $1.0 \mathrm{~m}$ in the experimental unit center for each treatment.

Air temperature was measured using three replicates of thermocouple sensors (thickness, $0.5 \mathrm{~mm}$; Copper-Constantan Type T), protected by a white shelter. The thermocouples were installed $0.03 \mathrm{~m}$ above the ground surface $(\mathrm{Ta} 0.03)$. Air temperature was also measured at $0.27 \mathrm{~m}$ above the soil surface $(\mathrm{Ta} 0.27)$ using a Pt-100 thermistor, forming a pair with a capacitive sensor to measure air humidity (HC2S3, Campbell Scientific, Logan, USA). Canopy surface temperature (Ts) was measured using an infrared thermometry sensor (SI-111, Apogee Instruments, Logan, UT, USA). The sensor was installed approximately $0.5 \mathrm{~m}$ above the canopy surface at 
an angle of $45^{\circ}$ relative to the ground, oriented so that its reading area would cover approximately $0.5 \mathrm{~m}^{2}$. All sensors (Copper-Constantan Type T, HC2S3 capacitive sensor, and SI-111 infrared thermometry sensor) were positioned along one of the plant lines.

Leaf (Lf) and rosette (Tr) temperatures were measured using copper-constantan thermocouples (thickness, 0.15 $\mathrm{mm}$; Type T). Sensors thermocouples were installed inside the main veins of developed and fully exposed leaves was measured. Tr was measured in the second experiment, between June 18 and June 25, because plants had one leaf during that frost. For these evaluations, three sensors were installed per treatment in different canola plants, located in the center of the experimental unit, totaling 12 sensors per frost. In the third experiment, Lf measurements were instead made with a portable infrared thermometer (UX-40, Ircon, New Dehli, India) ( $\varepsilon=$ 0.98). Evaluations were performed on three plants (three replicates) located in the center of the experimental unit per treatment. The first reading was taken at 04:00 and then repeated every half hour until 08:00.

Measurements of NR, G, Ta0.03, Ta0.27, Ts, and Lf were made every $30 \mathrm{~s}$, with averages calculated every 15 min. Measurements of U and UD were taken every $30 \mathrm{~s}$. Data were stored in a datalogger (CR 1000, Campbell Scientific, Loughborough, UK).

The minimum grass temperature ( $\mathrm{Tg})$ at the Passo Fundo/RS weather station $\left(28^{\circ} 23^{\prime} \mathrm{S}, 52^{\circ} 40^{\prime} \mathrm{W}\right.$; altitude, $\left.681 \mathrm{~m}\right)$ was used to define the dates at which frost occurred $\left(\mathrm{Tg} \leq 0^{\circ} \mathrm{C}\right)$. A total of 15 frost days were identified for 2014: three of weak intensity $(08 / 05,08 / 13$, and $08 / 26)$, seven of moderate intensity $(05 / 24,06 / 02,06 / 03,06 / 20,07 / 19$, $26 / 07$, and $08 / 27)$, two of average intensity ( $07 / 25$ and $08 / 28)$, and two of strong intensity (06/19 and 08/14) (Table 1), according to the classification system proposed by Araujo et al. (2012).

Micrometeorological variables were characterized for the frosts of 05/24, 06/19, 07/26, and 08/14. In these frosts, the canola phenological stages were B5, B1, C1, and B3, respectively (Table 1). The characterization of thermal conditions was based on Ta0.27.

Table 1. Dates (in 2014) of frost occurrence, frost intensity, and minimum grass temperature at the Passo Fundo weather station (Tng); minimum air temperature at $0.27 \mathrm{~m}$ above the ground surface (Tna0.27) in the experimental area, and canola plant development stage on the date of frost occurrence

\begin{tabular}{lllll}
\hline Frost occurrence date & Frost intensity & Tng $\left({ }^{\circ} \mathrm{C}\right)$ & Tna0.27 $\left({ }^{\circ} \mathrm{C}\right)$ & Phenological stage \\
\hline $05 / 24$ & Moderate & -2.5 & 0.56 & B5 \\
$06 / 02$ & Moderate & -2.6 & 1.32 & $\mathrm{C} 1$ \\
$06 / 03$ & Moderate & -2.8 & 1.59 & $\mathrm{C} 1$ \\
$06 / 19$ & Strong & -6.4 & -0.41 & B1 and D1 \\
$06 / 20$ & Moderate & -3.6 & 1.63 & B1 and D1 \\
$07 / 19$ & Moderate & -3.4 & 1.12 & B6 \\
$07 / 25$ & Average & -4.3 & 1.47 & $\mathrm{C} 1$ \\
$07 / 26$ & Moderate & -3.4 & -0.33 & $\mathrm{C} 1$ \\
$07 / 27$ & Moderate & -2.0 & 1.23 & $\mathrm{C} 1$ \\
$08 / 05$ & Weak & -0.6 & 2.50 & $\mathrm{~B} 1$ and D1 \\
$08 / 13$ & Weak & -0.1 & -0.32 & $\mathrm{~B} 3$ and D2 \\
$08 / 14$ & Strong & -7.7 & -3.31 & B3 and D2 \\
$08 / 26$ & Weak & -1.0 & 1.01 & B5 \\
$08 / 27$ & Moderate & -2.4 & 1.07 & B5 \\
$08 / 28$ & Average & -5.7 & -0.56 & B5 \\
\hline
\end{tabular}

Note. B1, one leaf developed; B3, three leaves developed; B5, five leaves developed; B6, six leaves developed; $\mathrm{C}$, new leaves appeared (final rosette period); D1, visible inflorescence; D2, bud covered with visible secondary inflorescences.

The dew point temperature $\left({ }^{\circ} \mathrm{C}\right.$; Tdp) was calculated using the Tetens equation, based on $\mathrm{Ta} 0.27$ and relative humidity (RH):

$$
\operatorname{Tdp}=\frac{237.3 \cdot \ln \left[\frac{e a}{6.108}\right]}{17.3-\ln \left[\frac{e a}{6.108}\right]}
$$

where, $e a$ is the vapor pressure (hPa), and was calculated as follows: 


$$
e a=(R H \cdot e s) / 100
$$

where, es is the saturated vapor pressure $(\mathrm{hPa})$. es was calculated as follows:

$$
\text { es }=6.108 \times 10^{7.5 \mathrm{Ta} 0.27 /(237.5+\mathrm{Ta} 0.27)}
$$

An analysis of variance (ANOVA) was used to assess both plant mortality and Lf. Averages were compared using a Tukey's test $(p=0.05)$. The other variables were used to characterize the effects of straw cover on micrometeorological conditions during frost events.

\section{Results and Discussion}

\subsection{General Conditions of Overnight Frost Events}

The average Tdp values between 18:00 and 08:00 on 05/24, 06/19,07/26, and 08/14 were 4.17, 2.20, 1.68 and $1.19^{\circ} \mathrm{C}$, respectively (Figures 1, 2, 3, and 4). Favorable conditions for surface and air cooling occurred on four dates, especially on three of these $(06 / 19,07 / 26$, and $08 / 14)$, when Tdp was below Ta0.27 at the beginning of the night. Tdp is indicative of the vapor content and latent heat of the air (Snyder \& Melo-Abreu, 2010).

On the night of $05 / 24$, fog formed when $U$ was above $1 \mathrm{~m} \mathrm{~s}^{-1}$ (Figure 1), a level that favors the mixing of stratified cold air layers, promoting condensation of excess vapor (Nemitz, 2009). The U value was above $1 \mathrm{~m} \mathrm{~s}^{-1}$ from 23:10 to $00: 20$, resulting in an increase of $2.12^{\circ} \mathrm{C}$ for Ta0.27. Thus, both Ta0.27 and Tdp remained the same until 00:20 (Figure 1); this was a necessary condition for fog formation, which reduced the loss of radiation energy from the ground surface, thus attenuating cooling and maintaining NR at near zero (Figure 1). When U fell below $1 \mathrm{~m} \mathrm{~s}^{-1}$, Tdp and Ta0.27 also reduced. Thus, Ta0.27 was slightly higher than Tdp (00:00 to 02:30), thus reducing fog formation. After 02:30, Ta0.27 returned to the same value as Tdp, but the NR data allowed us to infer that there was no longer any fog. 

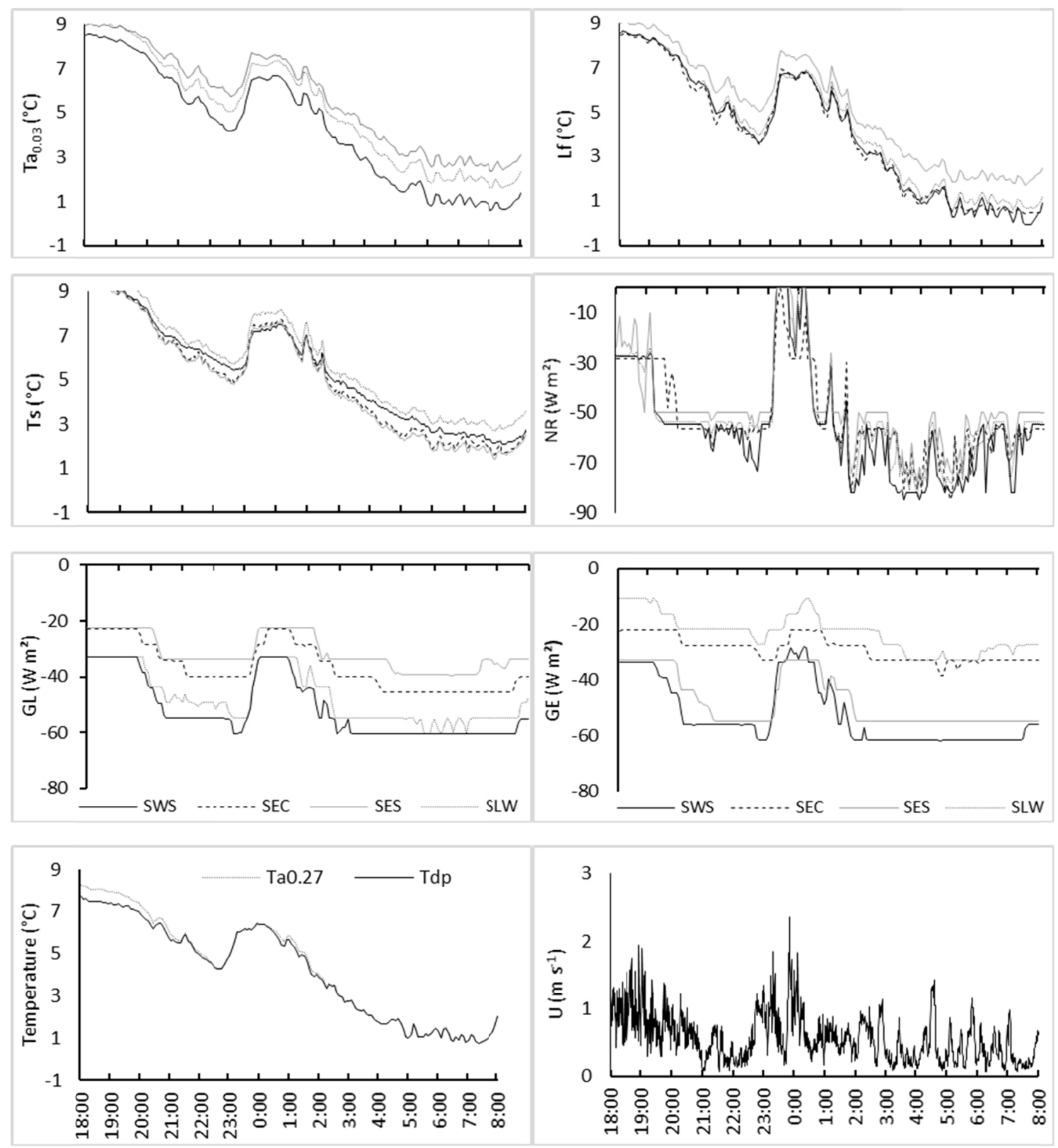

Figure 1. Microclimate parameters for canola plants measured at the experimental site in Coxilha, RS, Brazil on 05/24/2014 from 18:00 to 08:00

Note. Parameters measured: air temperature at a height of $0.03 \mathrm{~m}$ from the ground (Ta0.03), leaf temperature (Lf), surface temperature (Ts), net radiation (NR), soil heat flux on the plant line (GL) and between plant lines (GE), air temperature at a height of $0.27 \mathrm{~m}$ from the ground (Ta0.27), dew point temperature (Tdp), and wind speed (U). Experimental conditions: areas of ground without surface straw (SWS), completely covered with straw (SEC), with preexisting surface straw (SES), and without straw on the sowing line (SLW). Evaluations carried out in the experiment 1 (sowing date: April 23). 

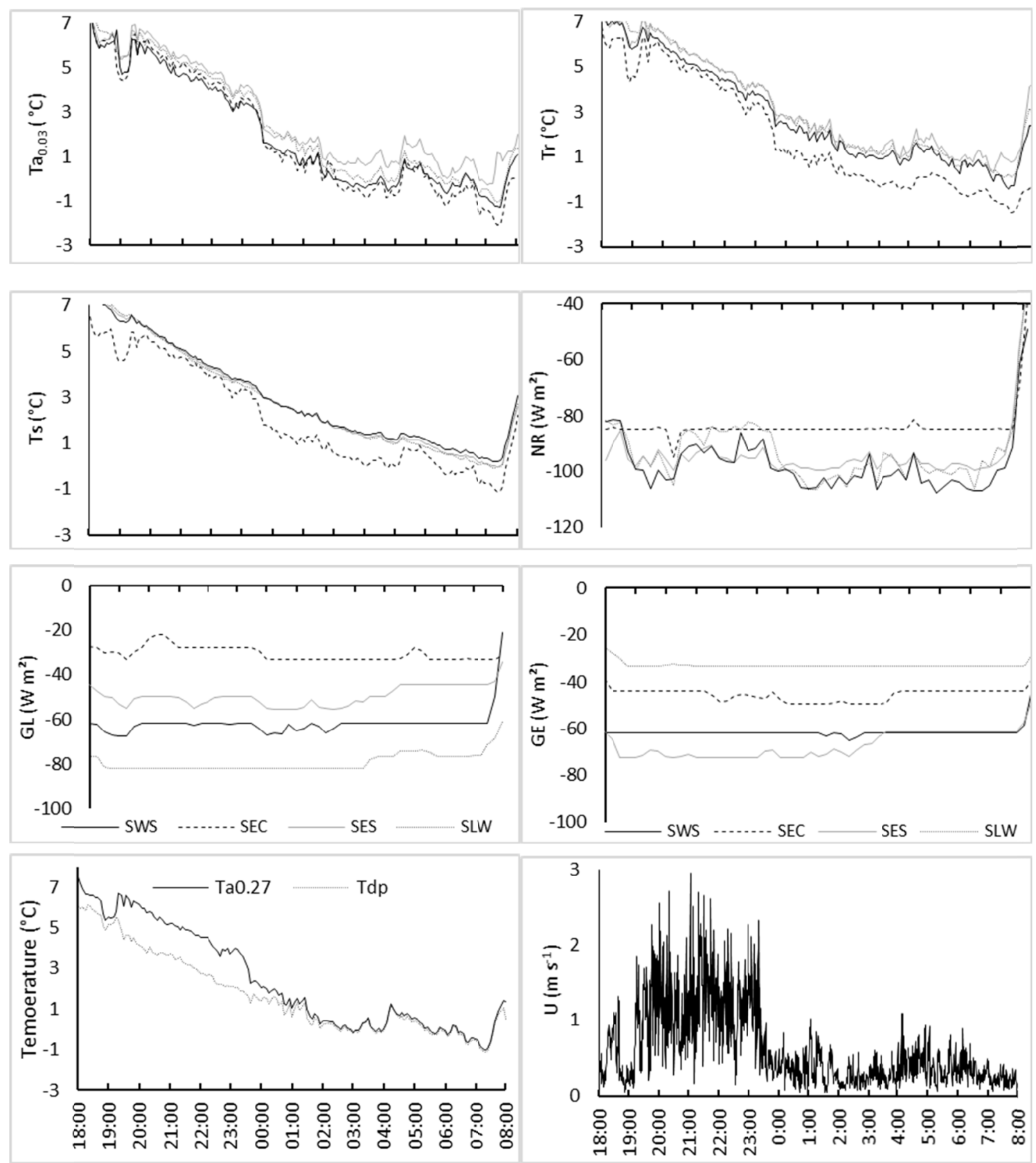

Figure 2. Microclimate parameters for canola plants measured at the experimental site in Coxilha, RS, Brazil on 06/19/2014 from 18:00 to 08:00

Note. Parameters measured: air temperature at a height of $0.03 \mathrm{~m}$ from the ground $(\mathrm{Ta} 0.03)$, rosette temperature (Tr), surface temperature (Ts), net radiation (NR), soil heat flux on the plant line (GL) and between plant lines (GE), dew point temperature (Tdp), air temperature at a height of $0.27 \mathrm{~m}$ from the ground (Ta0.27), and wind speed (U). Experimental conditions: areas of ground without surface straw (SWS), completely covered with straw (SEC), with preexisting surface straw (SES), and without straw on the sow line (SLW). Evaluations carried out in the experiment 2 (sowing date: May 29). 

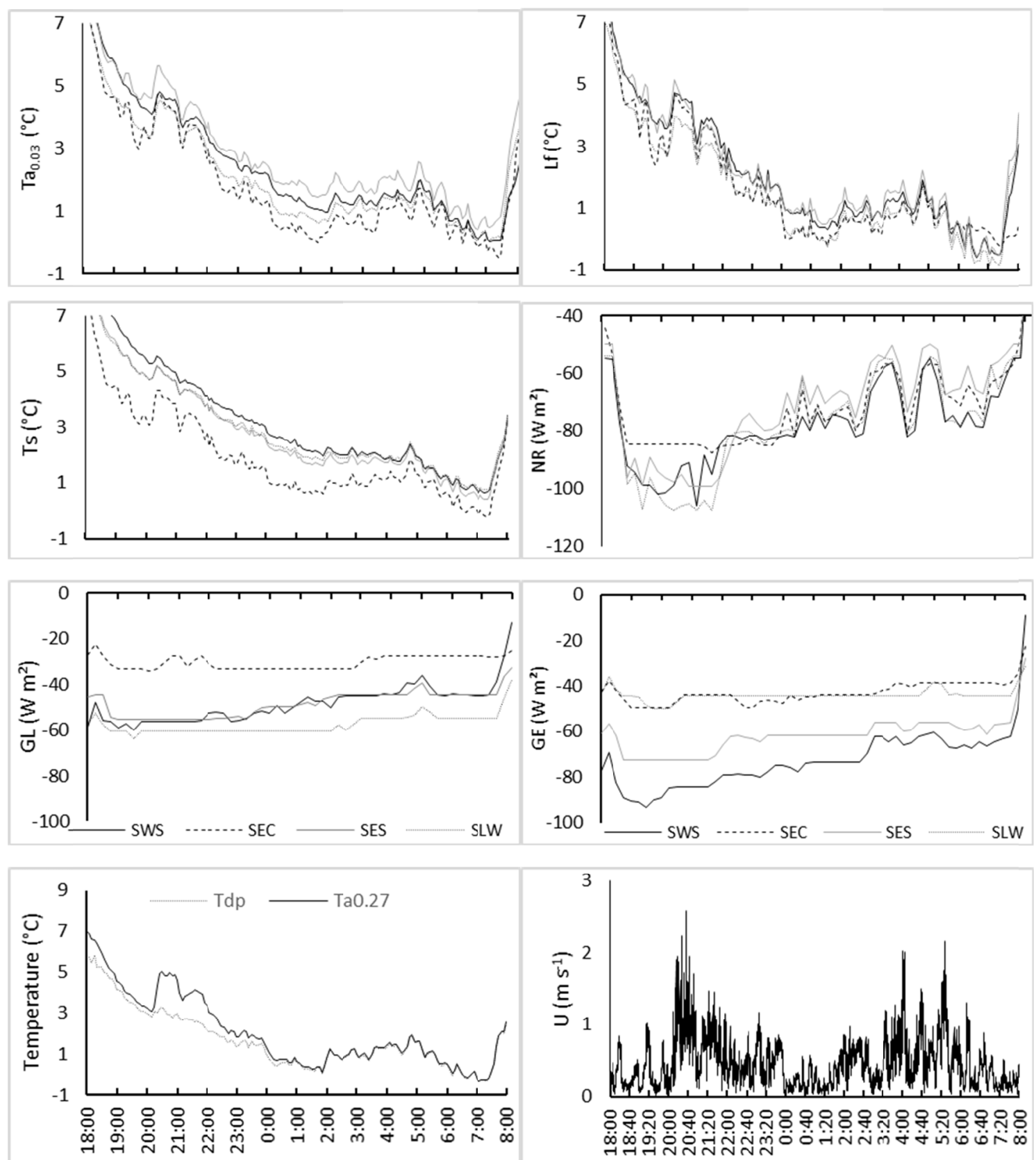

Figure 3. Microclimate parameters for canola plants measured at the experimental site in Coxilha, RS, Brazil on 07/26/2014 from 18:00 to 08:00

Note. Parameters measured: air temperature at a height of $0.03 \mathrm{~m}$ from the ground (Ta0.03), leaf temperature (Lf), surface temperature (Ts), net radiation (NR), soil heat flux on the plant line (GL) and between plant lines (GE), dew point temperature (Tdp), air temperature at a height of $0.27 \mathrm{~m}$ from the ground (Ta0.27), and wind speed (U). Experimental conditions: areas of ground without surface straw (SWS), completely covered with straw (SEC), with preexisting surface straw (SES), and without straw on the sow line (SLW). Evaluations carried out in the experiment 2 (sowing date: May 29). 

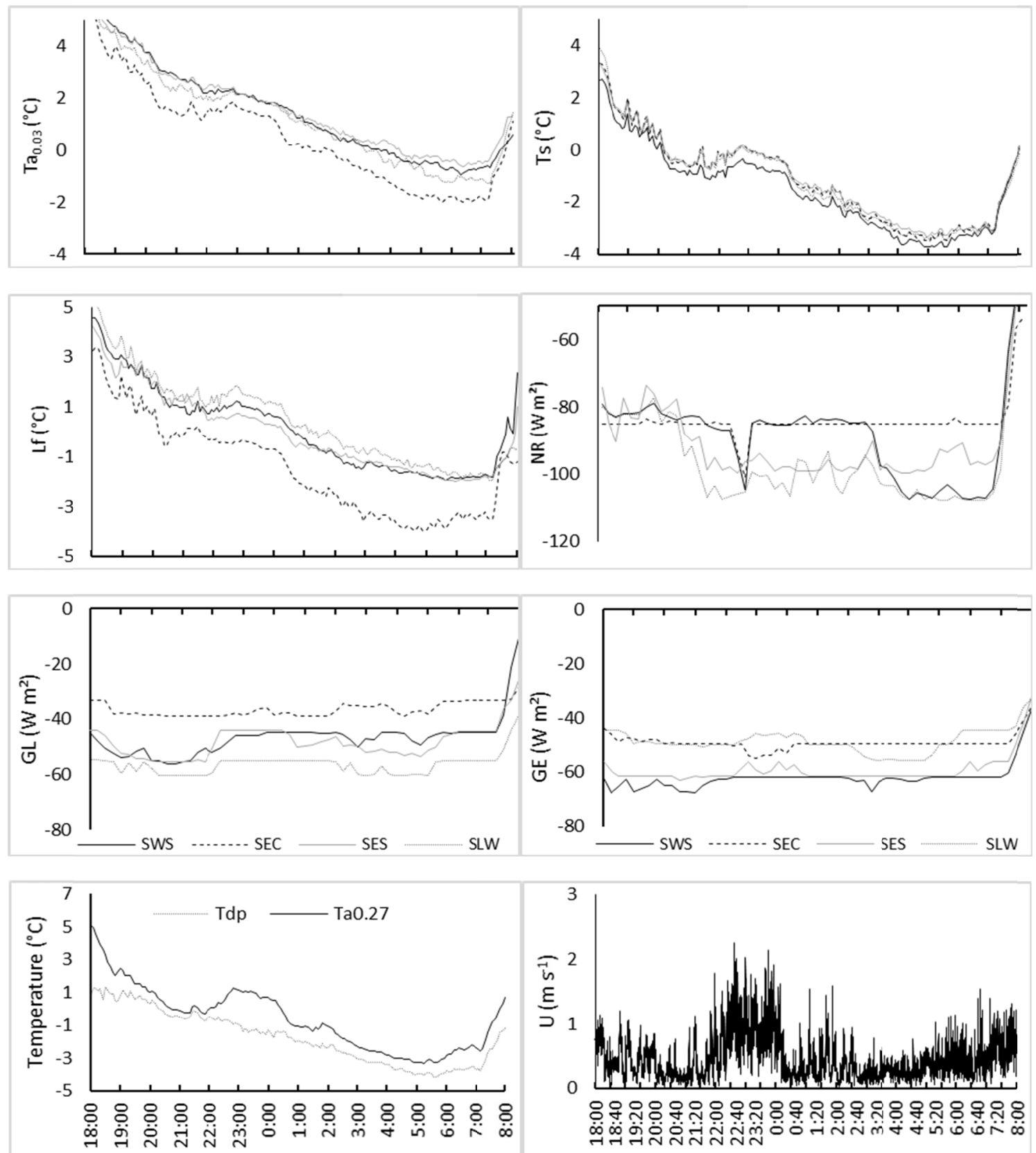

Figure 4. Microclimate parameters for canola plants measured at the experimental site in Coxilha, RS, Brazil on 08/14/2014 from 18:00 to 08:00

Note. Parameters measured: air temperature at a height of $0.03 \mathrm{~m}$ from the ground (Ta0.03), leaf temperature (Lf), surface temperature (Ts), net radiation (NR), soil heat flux on the plant line (GL) and between plant lines (GE), dew point temperature (Tdp), air temperature at a height of $0.27 \mathrm{~m}$ from the ground (Ta0.27), wind speed (U). Experimental conditions: areas of ground without surface straw (SWS), completely covered with straw (SEC), with preexisting surface straw (SES), and without straw on the sow line (SLW). Evaluations carried out in the experiment 2 (sowing date: May 29).

Periods when $\mathrm{U}$ was above $1 \mathrm{~m} \mathrm{~s}^{-1}$ occurred on the nights of 06/19, 07/26, and 08/14, and Ta0.27 also increased (Figures 2,3, and 4). However, the NR value on these dates indicated fog had not formed because NR was lower than on 05/24 (Figures 2, 3, and 4). The coldest frost occurred on 08/14, when Tdp was always below Ta0.27 and decreased linearly until reaching the minimum air temperature at $0.27 \mathrm{~m}$ above the soil surface $(\mathrm{Tna} 0.27=$ $-3.31^{\circ} \mathrm{C}$; at $\left.05: 15\right)$ (Figure 4). Similar responses were observed in other frost events $(05 / 24,06 / 19$, and 07/26); in 
these frosts, however, the difference between Ta0.27 and Tdp was lower than on 08/14 because the air vapor content was higher in comparison (Figures 2, 3, and 4).

\subsection{Plant Mortality, and Temperature of Leaves and Rosettes}

In the SEC treatment, canola plant mortality was $30 \%$ and $33.8 \%$ after the frost events of $06 / 19$ and $08 / 14$, respectively (Table 2). The lower thermal conductivity of soil covered with straw $\left(0.18 \mathrm{~W} \mathrm{~m}^{-1} \mathrm{~K}\right)$ when compared with uncovered clay soil $\left(0.56 \mathrm{~W} \mathrm{~m}^{-1} \mathrm{~K}\right.$ ) (Ahn et al., 2009) reduced the energy exchange between the soil and atmosphere. This resulted in greater cooling in straw-covered soil, resulting in the higher canola plant mortality observed in the SEC treatment compared with the other treatments (Kaspar \& Erbach, 1998; Cierniewski et al., 2015; O’Brien \& Daigh, 2019).

Table 2. Mortality rate (\%) of canola plants 7 (A7) and 14 (A14) days after the occurrence of frost (AG) at the experimental site (Coxilha, RS, Brazil) in 2014 on soil with no surface straw (SWS), soil entirely covered with straw (SEC), soil with preexisting straw on the surface (SES), and no straw on the seeding line (SLW)

\begin{tabular}{|c|c|c|c|c|c|c|}
\hline \multirow{2}{*}{ Frost dates } & \multirow{2}{*}{ Evaluation date } & \multicolumn{4}{|c|}{ Plant mortality per treatment $(\%)$} & \multirow{2}{*}{$\mathrm{CV}(\%)$} \\
\hline & & SWS & SEC & SES & SLW & \\
\hline \multirow{3}{*}{$05 / 24$} & $05 / 23(\mathrm{AG})$ & $0 \mathrm{~A}$ & $0 \mathrm{~A}$ & $0 \mathrm{~A}$ & $0 \mathrm{~A}$ & 0 \\
\hline & $05 / 30(\mathrm{~A} 7)$ & $0 \mathrm{~A}$ & $0 \mathrm{~A}$ & $0 \mathrm{~A}$ & $0 \mathrm{~A}$ & 0 \\
\hline & 06/07 (A14) & $0 \mathrm{~A}$ & $0 \mathrm{~A}$ & $0 \mathrm{~A}$ & $0 \mathrm{~A}$ & 0 \\
\hline \multirow{3}{*}{$06 / 02$ and $06 / 03$} & $06 / 01(\mathrm{AG})$ & $0 \mathrm{~A}$ & $0 \mathrm{~A}$ & $0 \mathrm{~A}$ & $0 \mathrm{~A}$ & 0 \\
\hline & 06/08 (A7) & $0 \mathrm{~A}$ & $0 \mathrm{~A}$ & $0 \mathrm{~A}$ & $0 \mathrm{~A}$ & 0 \\
\hline & 06/15 (A14) & $0 \mathrm{~A}$ & $0 \mathrm{~A}$ & $0 \mathrm{~A}$ & $0 \mathrm{~A}$ & 0 \\
\hline \multirow{3}{*}{$06 / 19$ and $06 / 20$} & $06 / 18(\mathrm{AG})$ & $0 \mathrm{~A}$ & $0 \mathrm{~A}$ & $0 \mathrm{~A}$ & $0 \mathrm{~A}$ & 0 \\
\hline & $06 / 26(\mathrm{~A} 7)$ & $0 \mathrm{~A}$ & $8.3 \mathrm{~B}$ & $0 \mathrm{~A}$ & $0 \mathrm{~A}$ & 8.4 \\
\hline & 07/03 (A14) & $0 \mathrm{~A}$ & $30.0 \mathrm{~B}$ & $5.5 \mathrm{~A}$ & $0 \mathrm{~A}$ & 8.0 \\
\hline \multirow{3}{*}{$07 / 19$} & $07 / 18(\mathrm{AG})$ & $0 \mathrm{~A}$ & $0 \mathrm{~A}$ & $0 \mathrm{~A}$ & $0 \mathrm{~A}$ & 0 \\
\hline & $07 / 25(\mathrm{~A} 7)$ & $0 \mathrm{~A}$ & $0 \mathrm{~A}$ & $0 \mathrm{~A}$ & $0 \mathrm{~A}$ & 0 \\
\hline & 08/02 (A14) & $0 \mathrm{~A}$ & $0 \mathrm{~A}$ & $0 \mathrm{~A}$ & $0 \mathrm{~A}$ & 0 \\
\hline \multirow{3}{*}{$07 / 25,07 / 26$, and $07 / 27$} & $07 / 24(\mathrm{AG})$ & $0 \mathrm{~A}$ & $0 \mathrm{~A}$ & $0 \mathrm{~A}$ & $0 \mathrm{~A}$ & 0 \\
\hline & $07 / 31(\mathrm{~A} 7)$ & $0 \mathrm{~A}$ & $0 \mathrm{~A}$ & $0 \mathrm{~A}$ & $0 \mathrm{~A}$ & 0 \\
\hline & 08/07 (A14) & $0 \mathrm{~A}$ & $0 \mathrm{~A}$ & $0 \mathrm{~A}$ & $0 \mathrm{~A}$ & 0 \\
\hline \multirow{3}{*}{$08 / 14$} & $08 / 13(\mathrm{AG})$ & $0 \mathrm{~A}$ & $0 \mathrm{~A}$ & $0 \mathrm{~A}$ & $0 \mathrm{~A}$ & 0 \\
\hline & $08 / 20(\mathrm{~A} 7)$ & $0 \mathrm{~A}$ & $7.5 \mathrm{~B}$ & $0 \mathrm{~A}$ & $0 \mathrm{~A}$ & 7.7 \\
\hline & 08/27 (A14) & $8.8 \mathrm{~A}$ & $33.8 \mathrm{~B}$ & $1.0 \mathrm{~A}$ & $1.3 \mathrm{~A}$ & 7.5 \\
\hline \multirow{3}{*}{$08 / 26,08 / 27$, and $08 / 28$} & $08 / 25(\mathrm{AG})$ & $0 \mathrm{~A}$ & $0 \mathrm{~A}$ & $0 \mathrm{~A}$ & $0 \mathrm{~A}$ & 0 \\
\hline & 09/01 (A7) & $0 \mathrm{~A}$ & $0 \mathrm{~A}$ & $0 \mathrm{~A}$ & $0 \mathrm{~A}$ & 0 \\
\hline & 09/08 (A14) & $0 \mathrm{~A}$ & $0 \mathrm{~A}$ & $0 \mathrm{~A}$ & $0 \mathrm{~A}$ & 0 \\
\hline
\end{tabular}

Note. $\mathrm{CV}$, coefficient of variation; Averages followed by the same lower case letter indicate there are no significant differences (Tukey's test, $\mathrm{p}>5 \%$ ) at each frost date.

During the frost event of 06/19, from 06:40 to 07:30, canola plants in the SEC and SLW treatments were exposed to Ta0.03 values ranging from $-1.3{ }^{\circ} \mathrm{C}$ to $-2.1{ }^{\circ} \mathrm{C}$ and $-0.6{ }^{\circ} \mathrm{C}$ to $-1.3{ }^{\circ} \mathrm{C}$, respectively. As a result, several dead plants were recorded in the SEC treatment 14 days after the frost, but none in the SLW treatment (Table 2). Therefore, it is possible to infer that mortality of canola plants in development stage B1 occurs at air temperatures of at least $-1.3{ }^{\circ} \mathrm{C}$ to $-2.1{ }^{\circ} \mathrm{C}$ under the conditions established in this experiment.

These values are similar to those determined by Wilen et al. (1994) and Dalmago et al. (2010), who found that air temperatures below $-2.0^{\circ} \mathrm{C}$ can cause plant death in the early development stages. The absence of straw in the SWS treatment accounts for the higher Ta0.03 values compared with those in the SEC and SLW treatments.

During the frost event of $06 / 19$, from $06: 40$ to $07: 30$, the average $\operatorname{Tr}$ values ranged from $-0.7^{\circ} \mathrm{C}$ to $-1.5^{\circ} \mathrm{C}$ in the SEC treatment and $0.2{ }^{\circ} \mathrm{C}$ to $-035^{\circ} \mathrm{C}$ in the SLW treatment (Figure 2). Tr was higher than Ta 0.03 , probably due to the proximity of the rosettes to the ground surface $(\approx 1 \mathrm{~cm})$, which contributed, in part, to the reduced energy loss 
from the plants. In the SEC treatment, Tr was lower than in the other treatments (Figure 2), due to the greater distance from the ground surface and direct contact with the straw.

Canola plants in the third experiment had three developed leaves by the frost of 08/14. From 04:00 to 06:30, Lf was lower in SEC than in the other treatments (Table 3), which resulted in a higher plant mortality (Table 2). NR and Ts increased at sunrise (07:02), followed by Ta0.03 and Lf (Figure 4 and Table 3). Thus, at 07:00, there was no difference in Lf between the SEC and SES treatments (Table 3). From 07:00 to 07:30, Lf fell in the SWS treatment, remained stable in the SLW treatment, and increased in both the SEC and SES treatments (Table 3). The straw on the soil surface warmed more quickly than the bare soil surface because of the low thermal conductivity, low specific heat, and greater degree of aerodynamic roughness (Van Doren \& Allmaras, 1978; Horton et al., 1996; Ahn et al., 2009; Lal \& Stewart, 2012). This resulted in a larger increase in Ta0.03 and Lf in SEC compared with the other treatments.

Table 3. Leaf temperature (third leaf developed) of canola plants on a day of frost $(08 / 14 / 2014)$ at the experimental site (Coxilha, RS, Brazil) in soil without surface straw (SWS), soil entirely covered with straw (SEC), soil with preexisting straw on surface (SES), and no straw on the seeding line (SLW)

\begin{tabular}{lllllllllll}
\hline \multirow{2}{*}{ Treatment } & \multicolumn{10}{c}{ Average leaf temperature $\left({ }^{\circ} \mathrm{C}\right)$} \\
\cline { 2 - 11 } & $04: 00$ & $04: 30$ & $05: 00$ & $05: 30$ & $06: 00$ & $06: 30$ & $07: 00$ & $07: 30$ & $08: 00$ & Average \\
\hline SWS & $-1.34 \mathrm{a}$ & $-3.42 \mathrm{a}$ & $-3.16 \mathrm{a}$ & $-3.50 \mathrm{a}$ & $-3.42 \mathrm{a}$ & $-3.73 \mathrm{a}$ & $-3.02 \mathrm{a}$ & $-3.24 \mathrm{a}$ & $0.47 \mathrm{~b}$ & -2.71 \\
SEC & $-2.74 \mathrm{~b}$ & $-5.42 \mathrm{c}$ & $-4.68 \mathrm{c}$ & $-5.12 \mathrm{c}$ & $-4.62 \mathrm{~b}$ & $-5.39 \mathrm{c}$ & $-3.79 \mathrm{~b}$ & $-2.94 \mathrm{a}$ & $2.12 \mathrm{a}$ & -3.62 \\
SES & $-1.36 \mathrm{a}$ & $-3.94 \mathrm{~b}$ & $-3.77 \mathrm{~b}$ & $-3.95 \mathrm{ab}$ & $-3.63 \mathrm{a}$ & $-4.48 \mathrm{~b}$ & $-3.47 \mathrm{ab}$ & $-3.15 \mathrm{a}$ & $0.56 \mathrm{~b}$ & -3.06 \\
SLW & $-1.85 \mathrm{a}$ & $-3.84 \mathrm{ab}$ & $-3.49 \mathrm{ab}$ & $-3.98 \mathrm{~b}$ & $-3.7 \mathrm{a}$ & $-3.83 \mathrm{a}$ & $-2.83 \mathrm{a}$ & $-2.85 \mathrm{a}$ & $0.68 \mathrm{~b}$ & -2.88 \\
- Average & -1.84 & -4.16 & -3.78 & -4.13 & -3.84 & -4.36 & -3.28 & -3.05 & 0.89 & - \\
CV (\%) & 22.18 & 9.12 & 11.8 & 8.45 & 12.28 & 13.87 & 17.85 & 24.55 & 98.49 & - \\
\hline
\end{tabular}

Note. Averages followed by the same lower case letter indicate there are no significant differences (Tukey's test, $\mathrm{p}>5 \%$ ) at each time period. Approximately $20 \mathrm{~min}$ was required to generate the reading for each time period. CV, coefficient of variation.

From 07:30 to $08: 00$, Lf increased by $3.71{ }^{\circ} \mathrm{C}, 3.53{ }^{\circ} \mathrm{C}, 3.71{ }^{\circ} \mathrm{C}$, and $5.06{ }^{\circ} \mathrm{C}$ in the SES, SLW, SWS, and SEC treatments, respectively (Table 3). According to Pearce (2001), Bredow and Walker (2017), Palta and Weiss (2018), Takahashi et al. (2019), Hincha and Zuther (2020), Ramlov and Friss (2020), the main cause of frost-related damage is the formation of extracellular ice crystals, which have a lower vapor pressure relative to liquid water in the cytoplasm, and promote the intracellular transfer of water to intercellular spaces. The rapid increase in Lf on frosty mornings precipitates thawing and exacerbates the potential for cellular damage. Slow thawing processes favor gradual hydration of cell membranes and, consequently, cell recovery. Straw on the soil surface does not assist in this process, as it accelerates warming early in the morning and exacerbates cooling at night, both of which increase the potential for frost damage in plants.

\subsection{Net Radiation and Heat Flux From the Soil}

During the nights of the evaluated frosts, NR varied between values close to $0 \mathrm{~W} \mathrm{~m}^{-2}$ and $-108 \mathrm{~W} \mathrm{~m}^{-2}$; the lowest values occurred during the most intense frosts $(06 / 19,07 / 26$, and $08 / 14)$, while higher values occurred during the frost of $05 / 24$ (Figures 1, 2, 3, and 4). On 08/14, when the most intense frost occurred (Tna0.27 $=-3.31{ }^{\circ} \mathrm{C}$ ), NR averaged $-85.3 \mathrm{~W} \mathrm{~m}^{-2},-90.5 \mathrm{~W} \mathrm{~m}^{-2},-92.9 \mathrm{~W} \mathrm{~m}^{-2}$, and $-98.4 \mathrm{~W} \mathrm{~m}^{-2}$ in the SEC, SWS, SES, and SLW treatments, respectively (Figure 4). The frost on $06 / 19\left(\mathrm{Tna} 0.27=-0.41^{\circ} \mathrm{C}\right)$ was less intense than that of $08 / 14$, but the average $\mathrm{NR}$ was similar between these two events. The average NR on $06 / 19$ was $-84.9 \mathrm{~W} \mathrm{~m}^{-2},-94.9 \mathrm{~W} \mathrm{~m}^{-2},-96.3 \mathrm{~W} \mathrm{~m}^{-2}$, and $-99.0 \mathrm{~W} \mathrm{~m}^{-2}$ in the SEC, SWS, SES, and SLW treatments, respectively (Figure 2). On 07/26 (Tna0.27 = $-0.33^{\circ} \mathrm{C}$ ), the average NR was higher than the frosts of $08 / 14$ and $06 / 19$, but followed the same trend. The average $\mathrm{NR}$ was $-71.9 \mathrm{~W} \mathrm{~m}^{-2},-76.8 \mathrm{~W} \mathrm{~m}^{-2},-70.8 \mathrm{~W} \mathrm{~m}^{-2}$, and $-76.6 \mathrm{~W} \mathrm{~m}^{-2}$ in the SEC, SLW, SES, and SWS treatments, respectively (Figure 3). On $05 / 24$, the average NR was $-52.0 \mathrm{~W} \mathrm{~m}^{-2},-56.0 \mathrm{~W} \mathrm{~m}^{-2},-47.7 \mathrm{~W} \mathrm{~m}^{-2}$, and $-52.5 \mathrm{~W} \mathrm{~m}^{-2}$ in the SEC, SWS, SES, and SLW treatments, respectively (Figure 1), indicating a lower loss of radiation from the surface than the frosts of 06/19, 7/26, and 08/14. In the evaluated frosts, the majority of SEC treatments had a higher NR compared with the other treatments. This response was more distinct during the intense frosts $(06 / 19$, $07 / 26$, and $08 / 14$ ) than in the lower intensity frost on $05 / 24$. 
The leaf area index (LAI) was negligible on 06/19, as the canola plants were at phenological stage B1 (one developed leaf). On 08/14, when canola plants were at phenological stage D2 (bud covered with visible secondary inflorescences), the LAI was 3.25, 2.38, 2.30, and 2.02 in the SWS, SES, SLW, and SEC treatments, respectively. Thus, the LAI may have contributed to reducing the difference in surface radiative energy loss between the frosts of 08/14 and 06/19. However, the amount and distribution of straw on the soil surface influenced the soil-air energy balance during frost events. A straw surface, such as in the SEC treatment, can reduce long-term energy loss by the emission of longwave radiation when compared with conditions such as in the bare soil (SWS), SES, and SLW treatments. Our results corroborated the observations of Cierniewski et al. (2015) and O'Brien and Daigh (2019), who suggested that straw acts as an insulator by restricting radiative exchange between the soil and atmosphere. Thus, surfaces with the largest amounts of straw on the soil surface displayed a lower energy loss from longwave radiation emission because they exhibit lower temperature values, according to the Stefan-Boltzmann law, which states that the energy radiated by a surface is proportional to the fourth power of its temperature (Snyder \& Melo Abreu, 2010). Azooz et al. (1997) found that in a soil with a $30 \mathrm{~cm}$ residue-free strip over the center of the row had significantly higher heat flow into the soil surface. These result indicated that a residue-free strip over the row center alternated with residue strip in between rows could be important in providing more heat input into the soil surface at the row center. Considering the NR results, the removal of straw from the sowing line (SLW treatment) promoted similar responses to a soil surface without straw (SWS treatment), which states that the energy radiated by a surface is proportional to the fourth power of its temperature.

\subsection{Surface Temperature}

The NR data indicated that ground surfaces in the SEC treatment were colder than in the other treatments (Figures $1,2,3$, and 4); this was confirmed by the average Ts data for $06 / 19\left(2.09{ }^{\circ} \mathrm{C}, 2.89^{\circ} \mathrm{C}, 2.93{ }^{\circ} \mathrm{C}\right.$, and $3.00^{\circ} \mathrm{C}$ in the SEC, SWS, SES, and SLW treatments, respectively) (Figure 2). However, Ts values did not correspond to NR values on $08 / 14$ because of the lower Ts values observed in the SWS treatment (Figure 4), probably due to LAI interference. In addition, the minimum Ta0.03 (below leaf level) was $-2.00{ }^{\circ} \mathrm{C}$, while Ta0.27 in the plant canopy was $-3.72{ }^{\circ} \mathrm{C}$. This difference supports the hypothesis that LAI interfered with nighttime NR by acting as a slight barrier that served to reduce radiative loss from the soil surface, thus slowing cooling in the lower third of the canopy.

On 05/24, higher NR and lower Ts values were recorded in the SES treatment (Figure 1), corroborating the StefanBoltzmann law (Snyder \& Melo Abreu, 2010). The occurrence of lower Ts values in the SES compared with the SEC treatment was probably due to the uneven distribution of straw on the soil surface in the former on $05 / 24$, which reduced energy loss from the ground (Figure 1).

On 07/26, NR values were lower in the SES compared with other treatments (Figure 3). The average NR values from 18:00 to 08:00 were $-85.2 \mathrm{~W} \mathrm{~m}^{-2},-103.7 \mathrm{~W} \mathrm{~m}^{-2},-96.3 \mathrm{~W} \mathrm{~m}^{-2}$, and $-96.7 \mathrm{~W} \mathrm{~m}^{-2}$ in the SEC, SLW, SES, and SWS treatments, respectively (Figure 3). An exception occurred between 18:45 and 21:30, when the SEC treatment exhibited lower NR values than in the other treatments (Figure 3). Lower Ts values also occurred in the SEC treatment from 18:45 to 21:30, therefore showing a trend consistent with NR (Figure 3). The average Ts values were $3.73{ }^{\circ} \mathrm{C}, 5.02{ }^{\circ} \mathrm{C}, 5.03{ }^{\circ} \mathrm{C}$, and $5.55{ }^{\circ} \mathrm{C}$ in the SEC, SLW, SES, and SWS treatments, respectively, and higher NR values occurred in the SEC treatment. From 21:30 to 08:00, the SWS treatment showed lower NR values, while lower Ts values occurred in the SEC treatment. This contradictory response of NR to Ts is probably related to interference by energy advection.

On 07/26, from $20: 10$ to $20: 30$, Ts values increased by $1.10^{\circ} \mathrm{C}, 0.51^{\circ} \mathrm{C}, 0.50^{\circ} \mathrm{C}$, and $0.28^{\circ} \mathrm{C}$ in the SEC, SLW, SWS, and SES treatments, respectively. This increase coincided with the increase in wind speed from $0.2 \mathrm{~m} \mathrm{~s}^{-1}$ to more than $1.0 \mathrm{~m} \mathrm{~s}^{-1}$ (Figure 3). This agreed with the hypothesis that energy advection occurred in the experimental area and/or forced air mixing occurred, changing the air temperature profile.

From 21:00 to $21: 10$, the wind speed was below $0.5 \mathrm{~m} \mathrm{~s}^{-1}$, and Ts decreased by $0.99{ }^{\circ} \mathrm{C}, 0.56{ }^{\circ} \mathrm{C}, 0.49{ }^{\circ} \mathrm{C}$, and $0.38^{\circ} \mathrm{C}$ in the SEC, SLW, SES, and SWS treatments, respectively (Figure 3). The reduction in Ts in the SEC treatment during this time period highlights the effects of soil surface mulching on reducing Ts on frost nights. In addition, the response of Ts values from 20:10 to 20:30 demonstrates how the energy advection effect (and/or forced air mixing changing the air temperature profile) can minimize Ts differences between straw-covered and bare soil surfaces, because of attenuation of cooling of the straw-covered soil surface. Energy advection in the surrounding areas (and/or homogenization of the air temperature profile) was the cause of the inconsistencies between NR and Ts values, the reasons for which could not be determined conclusively. However, oscillations in NR followed variations in wind speed, which is consistent with evidence that changes in wind speed directly affect NR. Fluctuations in NR values in response to wind speed changes were observed on all frost dates; on 05/24 and 
07/26 (low-intensity frost events), oscillations in NR values occurred in all the treatments (Figures 1 and 3), but occurred only in the SWS, SES, and SLW treatments on 06/19 and 08/14 (the two most intense frost events) (Figures 2 and 4).

On $06 / 19$ and $08 / 14$, NR values in the SEC treatment remained more or less constant over most of the monitored period and were lower than in the other treatments (Figures 2 and 4). The exceptions were between 20:30 and 23:30 on 06/19 and 18:00 and 03:00 on 08/14, when the SWS treatment showed similar NR values to the SEC treatment (Figures 2 and 4).This response shown in the SEC treatment was probably due to the greater cold intensity on 06/19 and 08/14.

Parity of measured values between the SEC and SWS treatments prevailed when the wind speed exceeded $1 \mathrm{~ms}^{-1}$, a speed considered by Nemitz (2009) to be sufficient to promote turbulence in the plant canopy. This may account for the similarity in NR values between these two treatments, given that it cannot be explained by their Ts values.

The lower Ts in the SEC treatment resulted in a lower Ta0.03 during the frost events of 06/19,07/26, and 08/14 (Figures 2, 3, and 4). On 05/24, the SEC treatment sensor did not record data. The average Ta0.03 from 18:00 to 08:00 on $06 / 19$ was $1.89^{\circ} \mathrm{C}$ in the SEC treatment, whereas air temperatures in the SLW, SWS, and SES treatments were $2.83{ }^{\circ} \mathrm{C}, 3.16^{\circ} \mathrm{C}$, and $3.23{ }^{\circ} \mathrm{C}$, respectively (Figure 2). On $08 / 14$, the average Ta0.03 values (i.e., measured below the leaves) were $0.54{ }^{\circ} \mathrm{C}, 1.26{ }^{\circ} \mathrm{C}, 1.49{ }^{\circ} \mathrm{C}$, and $1.62{ }^{\circ} \mathrm{C}$ in the SEC, SLW, SWS, and SES treatments, respectively (Figure 4).

Thus, the variables measured on the frost dates indicated that the form of soil-surface cover influenced NR (and consequently the energy balance), and also therefore the leaf, surface, and air temperatures. In addition, local topography favored energy advective transport from surrounding areas, which prevented a more pronounced freezing. Interference by energy advection may have lessened the effect of surface straw quantity and distribution on energy balance, and thus on the leaves, surfaces, and air, since lower temperatures occur when there is more straw. However, even taking energy advection into account, significant plant mortality occurred during frost events in treatments with more soil surface straw cover around cold-susceptible canola seedlings with no previous period of acclimation. Thus, due to the energy advection observed in this experiment, it can be inferred that soil surface straw should cause far more damage to young canola plants than in this experiment. Therefore, the removal of straw cover from the sowing line is an effective alternative to reducing frost damage on canola plants.

\section{Conclusions}

The results of the experiment showed that removing straw cover from the seeding line can reduce frost-related mortality in canola plants prior to developing three leaves (B3 stage). The air temperature near the surface of leaves and rosettes is lower on completely straw-covered soil than on soil without surface straw. Removing straw cover from $0.05 \mathrm{~m}$ on each side of the canola seeding line (i.e., a total of $0.10 \mathrm{~m}$ ) has a similar effect to the total removal of straw from the soil surface. An increase in wind speed at night associated with the occurrence of frost favors energy advection, and consequently attenuation of cooling.

\section{Acknowledgements}

The authors thank Capes, CNPq, Embrapa Trigo, and Universidade Federal de Santa Maria (UFSM) for their support.

\section{References}

Ahn, H. K., Sauer, T. J., \& Glanville, T. D. (2009). Determination of thermal properties of composting bulking materials. Bioresource Technology, 100(17), 3974-3981. https://doi.org/10.1016/j.biortech.2008.11.056

Alvares, C. A., Stape, J. L., Sentelhas, P. C., Gonçalves, J. L. M., \& Sparovek, G. (2013). Köppen's climate classification map for Brazil. Meteorologische Zeitschrift, 22(6), 711-728. https://doi.org/10.1127/09412948/2013/0507

Araujo, C. E. S., Massignan, A. M., \& Borges, R. C. (2012). Frost forecast in Santa Catarina State, Brazil. Revista Agropecuária Catarinense, 25(1), 87-90.

Azooz, R. H., Lowery, B., Daniel, T. C., \& Arshad, M. A. (1997). Impact of tillage and residue management on soil heat flux. Agricultural and Forest Meteorology, 84(3-4), 207-222. https://doi.org/10.1016/S0168-1923 (96)02364-7

Bredow, M., \& Walker, V. K. (2017). Ice-Binding in Plants. Frontiers in Plant Science, 8, 2153. https://doi.org/ 10.3389/fpls.2017.02153 
Chen, Y., \& McKyes, E. (1993). Reflectance of light from the soil surface in relation to tillage practices, crop residues and the growth of corn. Soil and Tillage Research, 26(2), 99-114. https://doi.org/10.1016/ 0167-1987(93)90037-P

Cierniewski, J., Karnieli, A., Kazmierowski, C., Krolewicz, S., Piekarczyk, J., Lewinska, K., ... Orzechowski, M. (2015). Effects of soil surface irregularities on the diurnal variation of soil broadband blue-sky albedo. IEEE Journal of Selected in Applied Earth Observations and Remote Sensing, 8(2), 493-502. https://doi.org/ 10.1109/JSTARS.2014.2330691

Davin, E. L., Seneviratne, S. I., Ciais, P., Olioso, A., \& Wang, T. (2014). Preferential cooling of hot extremes from cropland albedo management. Proceedings of the National Academy of Sciences, 111(27), 9757-9761. https://doi.org/10.1073/pnas.1317323111

Dalmago, G. A., Cunha, G. R., Santi, A., Pires, J. L. F., Müller, A. L., \& Bolis, L. M. (2010). Acclimatization to cold and frost-injury in canola. Pesquisa Agropecuária Brasileira, 45(9), 933-943. http://doi.org/10.1590/ S0100-204X2010000900001

Hincha, D. K., \& Zuther, E. (2020). Introduction: Plant cold acclimation and winter survival. In D. Hincha \& E. Zuther (Eds.), Plant cold acclimation. Methods in molecular Biology (Vol. 2156, pp. 1-7). New York, NY: Humana. https://doi.org/10.1007/978-1-0716-0660-5_1

Fiebelkorn, D., \& Rahman, M. (2016). Development of a protocol for frost-tolerance evaluation in rapesees/canola (Brassica napus L.). The Crop Journal, 4(2), 147-152. http://doi.org/10.1016/j.cj.2015.11.004

Frederiks, T. M., Christopher, J. T., Harvey, G. L., Sutherland, M. W., \& Borrell, A. K. (2012). Current and emerging screening methods to identify posthead-emergence frost adaptation in wheat and barley. Journal Experimental of Botany, 63(15), 5405-5416. https://doi.org/10.1093/jxb/ers215

Horton, R., Bristow, K. L., Kluitenberg, J., \& Sauer, T. J. (1996). Crop residue effects on surface radiation and energy balance-review. Theoretical and Applied Climatology, 54(1-2), 27-37. https://doi.org/10.1007/ BF00863556

Kaspar, T. C., \& Erbach, D. C. (1998). Improvement stand establishment in no-till with residue-clearing planter attachments. Transactions of the American Society of Agricultural Engineers, 41(2), 301-306.

Jan, S. A., Bibi, N., Shinwari, Z. K., Rabbani, M. A., Ullah, S., Qadir, A., \& Khan, N. (2017). Impact of salt, drought, heat and frost stresses on morpho-biochemical and physiological properties of Brassica species: An updated review. Journal of Rural Development and Agriculture, 2(1), 1-10.

Lal, R., \& Stewart, B. A. (2012). Soil water and agronomic productivity. Boca Raton, FL: CRC Press. https://doi.org/10.1201/b12214

Martino, D. L., \& Abbate, P. E. (2019). Frost damage on grain number in wheat at different spike developmental stages and its modelling. European Journal of Agronomy, 103, 13-23. https://doi.org/10.1016/j.eja.2018. 10.010

McClinchey, S. L., \& Kott, L. S. (2008). Production of mutants with high cold tolerance in spring canola (Brassica napus). Euphytica, 162(1), 51-67. https://doi.org/10.1007/s10681-007-9554-8

Nemitz, E., Loubet, B., Lehmann, B. E., Cellier, P., Neftel, A., Jones, S. K., .. Sutton, M. A. (2009). Turbulence characteristics in grassland canopies and implications for tracer transport. Biogeosciences Discussions, 6(8), 1519-1537. https://doi.org/10.5194/bg-6-1519-2009

O’Brien, P. L., \& Daigh, A. L. M. (2019). Tillage practices alter the surface energy balance-A review. Soil \& Tillage Research, 195, 104354. https://doi.org/10.1016/j.still.2019.104354

Palta, J. P., \& Weiss, L. S. (2018). Ice formation and freezing injury: an overview on the survivel mechanisms and molecular aspects of injury and cold acclimation in herbaceous plants. In P. H. Li \& L. Christersson (Eds.), Advances in plant cold hardiness (Vol. 11, pp. 143-176). Boca Raton: CRC Press. https://doi.org/ $10.1201 / 9781351069526-11$

Pearce, R. S. (2001). Plant freezing and damage. Annals of Botany, 87(4), 417-424. https://doi.org/10.1006/ anbo.2000.1352

Raine, S. R., \& So, H. B. (1993). An energy based parameter for the assessment of aggregate bond energy. European Journal of Soil Science, 44(2), 249-259. https://doi.org/10.1111/j.1365-2389.1993.tb00449.x 
Ramlov, H., \& Friss, D. S. (2020). Ice formation in living organisms. In H. Ramlov \& D. S. Friss (Eds.), Antifreeze proteins (Vol. 1, pp.53-82). Switzerland: Springer. https://doi.org/10.1007/978-3-030-41929-5_4

Snyder, R. L., \& Melo-Abreu, J. P. (2010). Protección contra las heladas: Fundamentos, practica y economia. Roma: Organização das Nações Unidas para a Agricultura e Alimentação (FAO).

Sovero, M. (1993). Rapeseed, a new oilseed crop for the United States. In J. Janick \& J. E. Simon (Eds.), New crops (pp. 302-307). New York: Wiley.

Takahashi, D., Gorka, M., Erban, A., Graf, A., Kopka, J., Zuther, E., \& Hincha, D. K. (2019). Both cold ad sub-zero acclimation induce cell wall modification and changes in the extracellular proteome in Arabidopsis thaliana. Scientific Reports, 9(1), 2289. https://doi.org/10.1038/s41598-019-38688-3

Thomas, P. (2003). Canola grower's manual. Retrieved from http://www.canolacouncil.org/crop-production/ canola-grower's-manual-contents

Van Doren Jr., D. M., \& Allmaras, R. R. (1978). Effect of residue management practices on the soil physical environment, microclimate, and plant growth. In W. R. Oschwald (Ed.), Crop residue management systems, Volume 31 (pp. 49-83). Madison, WI: ASA/CSSA/SSSA. https://doi.org/10.2134/asaspecpub31.c4

Wilen, R. W., Gusta, L. V., Lei, B., Abrams, S. R., \& Ewan, B. E. (1994). Effects of abcisic acid (ABA) and ABA analogs on freezing tolerance, low-temperature growth, and flowering in rapeseed. Journal of Plant Growth Regulation, 13(4), 235. https://doi.org/10.1007/BF00226043

\section{Copyrights}

Copyright for this article is retained by the author(s), with first publication rights granted to the journal.

This is an open-access article distributed under the terms and conditions of the Creative Commons Attribution license (http://creativecommons.org/licenses/by/4.0/). 